\title{
YIELD PERFORMANCE OF LENTIL AS A MIXED CROP WITH RAPESEED
}

\author{
M. S. Islam ${ }^{1}$, M. A. Islam $^{1 *}$, M. A. Begum², M. Maniruzzaman' ${ }^{1}$ and M. A. U. Alam ${ }^{1}$ \\ ${ }^{1}$ On Farm Research Division, Bangladesh Agricultural Research Institute, Agricultural Research Station, Pabna, ${ }^{2}$ Department of \\ Agronomy, Bangladesh Agricultural University, Mymensingh, \\ *Corresponding author: amin_bau@yahoo.com
}

Key words: lentil, lentil equivalent yield, mixed cropping, rapeseed

\begin{abstract}
Mixed crop cultivation of lentil and rapeseed could be a promising technology for yield maximization. The field experiment was carried out at multilocation testing site, Kashinathpur, Pabna during the rabi season of 2011-12 and 2012-13 to verify the performance of rapeseed as mixed crop with lentil at different seeding ratios. The treatment comprises for the experiment were $\mathrm{T}_{1}$ : Sole lentil (100\%), $\mathrm{T}_{2}$ : Sole rapeseed $(100 \%), \mathrm{T}_{3}$ : Lentil $(100 \%)+$ Rapeseed $(10 \%)$, $\mathrm{T}_{4}$ : Lentil (100\%) + Rapeseed (20\%), $\mathrm{T}_{5}$ : Lentil (100\%) + Rapeseed (30\%) and $\mathrm{T}_{6}$ :Farmers' practice :Lentil (100\%) + Rapeseed (15\%). The highest lentil equivalent yield $\left(2.22 \mathrm{t} \mathrm{ha}^{-1}\right.$ in and 2.48 ) and maximum land equivalent ratios (1.27 and 1.28) were observed in $\mathrm{T}_{4}$ treatment in 2011-12 and 2012-13, respectively.. It was noted that all the mixed cropping systems produced higher equivalent yield and LER than that of their corresponding sole crops. . Cost and return analysis showed that the highest net return (Tk. $127774 \mathrm{ha}^{-1}$ ) was found in $\mathrm{T}_{4}$ treatment while sole rapeseed gave the lowest net return (Tk. $60540 \mathrm{ha}^{-1}$ ). Net return was always higher under mixed cropping system than that of sole cropping. The highest benefit cost ratio 3.48 was recorded from Lentil (100\%) + Rapeseed (20\%) where as the minimum (1.39) from soli rapeseed..
\end{abstract}

\section{Introduction}

Lentil (Lens culinaris) is one of the important pulse crops, which ranks the first position regarding area and production in Bangladesh (BBS, 2010). It is one of the most important sources of protein both as food and feed. It also produces more stable yield and can be grown with minimum care. Lentil is generally grown as sole crop but it can also be grown as mixed or intercrop with maize, mustard, wheat, barley etc. On the other hand, mustard (Brassica spp.) is an important oil crop, which also ranks first position among the oil crops in Bangladesh (BBS, 2010).

Mixed cropping is the agricultural practice of cultivating two or more crops in the same piece of land at the same time (Ofori and Stern, 1987; Anil et al., 1998). It offers effective weed suppression, pest and disease control, and use of soil resources under organic farming systems (Bulson et al., 1997; Theunissen, 1997; Jensen et al., 2005). An ideal intercropping or mixed cropping system should aim to i) produce higher yields per unit area through better use of natural resources, minimizing the incidence of insect pests, diseases weeds and improving the nitrogen economy in legume associations, ii) Offer greater stability and crop insurance in production under aberrant weather condition, iii) Meet the domestic need of farmers and animal iv) provide an equitable distribution of farm resources (Ali, 1990). So, this trial was planned to evaluate the technological feasibility and economic validity of mixed cropping lentil with rapeseed at different seeding rates of rapeseed.

\section{Materials and Methods}

The experiment was carried out at MLT site, Kashinathpur, Pabna in the rabi season of 2011-12 and 2012-13. The soils of the experimental areas belong to the High Ganges River Flood Plain under AEZ-11. 
Islam et al.

The soils of the experimental plots were sandy clayey loam in texture. The experiment was laid out in Randomized Complete Block (RCB) design with six dispersed replications. It was consisted with six treatments as follows: $\mathrm{T}_{1}$ : Sole lentil (100\% lentil), $\mathrm{T}_{2}$ : Sole rapeseed (100\% rapeseed), $\mathrm{T}_{3}$ : Lentil $(100 \%)+$ Rapeseed (10\%), $\mathrm{T}_{4}$ : Lentil (100\%) + Rapeseed (20\%), $\mathrm{T}_{5}$ : Lentil (100\%) + Rapeseed (30\%) and $\mathrm{T}_{6}$ : Lentil (100\%) + Rapeseed (15\%). Seed rate $30 \mathrm{Kg} \mathrm{ha}^{-1}$ for lentil and $10 \mathrm{Kg} \mathrm{ha}^{-1}$ for rapeseed was considered for crop, respectively. To obtain 10, 15, 20,30\% rapeseed, amount of seed mixed with lentil was calculated as $1,1.5,2.0$ and $3.0 \mathrm{~kg} \mathrm{ha}^{-1}$. The calculated amounts of rapeseed were mixed with $30 \mathrm{~kg}$ of lentil seeds separately for achieving different treatment combinations (i.e. $\mathrm{T}_{3}, \mathrm{~T}_{6}, \mathrm{~T}_{4}$ and $\mathrm{T}_{5}$ treatments). Seeds of lentil (BARIMasur7) and rapeseed (BARISarisha14) were sown on $10^{\text {th }}$ to17 ${ }^{\text {th }}$ November in 2011 and $2^{\text {nd }}$ to $5^{\text {th }}$ November in 2012 as broadcast. The unit plot size was $7.5 \mathrm{~m} \mathrm{x} 4 \mathrm{~m}$. The lands were fertilized with 19, 16, 20, 7, 1.5 and $1.5 \mathrm{~kg} \mathrm{~N}-\mathrm{P}-\mathrm{K}-\mathrm{S}-\mathrm{Zn}-\mathrm{B} \mathrm{ha}^{-1}$ respectively for sole lentil and mixed cropping and 115, 34, 43, 27, 2.5 and $2.5 \mathrm{~kg} \mathrm{N-P-K-S-Zn-B} \mathrm{ha-1}$ for sole rapeseed. All the fertilizers of entire amount was applied during final land preparation as basal except $\mathrm{T}_{2}$ (sole rapeseed) as one third urea was applied as top dress at about 30 DAS on $20^{\text {th }}$ to $22^{\text {nd }}$ December, 2011 and $2^{\text {nd }}$ to $5^{\text {th }}$ December, 2012.

The treatments were evaluated in terms of land equivalent ratio (LER) using the following formula of Willey (1981).

LER $=\frac{\text { Yield of intercropped lentil }}{- \text { Yield of solecropped lentil }}+$ Yield of intercropped rapeseed

Also, rapeseed yields were converted into lentil equivalent yield as per Anjeneyula et al. (1982). Lentil yield equivalent

$$
\mathrm{Y}=\frac{\mathrm{Y}_{1} \times \mathrm{P}_{1}}{\mathrm{P}_{\mathrm{m}}}
$$

Where, $\mathrm{Y}_{\mathrm{l}}=$ Yield of lentil, $\mathrm{P}_{\mathrm{l}}$ and $\mathrm{P}_{\mathrm{m}}=$ Market prices of lentil and rapeseed, respectively.

The recorded data were statistically analyzed following Gomez and Gomez (1984). All types of variable production cost are recorded to find out the benefit cost ratio (BCR).

\section{Results and Discussion}

\section{Yield and yield attributes of lentil}

The results revealed that most of the yield attributes of lentil were significantly influenced due to mixed cropping with rapeseed except plant population (Table 1). Higher plant height (48.10 cm in 2011-12 and $50.63 \mathrm{~cm}$ in 2012-13) was obtained from $\mathrm{T}_{1}$ treatment followed by $\mathrm{T}_{3}$. The maximum number of pod plant $^{-1}$ (57.18 in 2011-12 and 46.55 in 2012-13) was recorded in $\mathrm{T}_{1}$ which was statistically identical to $\mathrm{T}_{3}, \mathrm{~T}_{4}$ and $\mathrm{T}_{6}$ treatments and the lowest number of pod plant ${ }^{-1}$ from $\mathrm{T}_{5}$ treatment. Pods plant ${ }^{-1}$, number of seeds pod $^{-1}$ was found significant in all the treatment combination in 2011-12 but statistical similarity in 2012-13 except $T_{5}$ treatment. In 2011-12 cropping season, 1000- seed weight was statistically similar in $\mathrm{T}_{1}, \mathrm{~T}_{3}, \mathrm{~T}_{4}$ and $\mathrm{T}_{6}$ but numerically higher 1000 seed weight (18.55g) was obtained from $\mathrm{T}_{3}$ and the lower (17.87g) from $T_{5}$ treatment where as in 2012-13 while maximum in $T_{1}(18.91 \mathrm{~g})$ followed by $\mathrm{T}_{3}(18.33$ $\mathrm{g}), \mathrm{T}_{4}(18.32 \mathrm{~g})$ and $\mathrm{T}_{6}(18.23 \mathrm{~g})$ and the lowest $(17.26 \mathrm{~g})$ in $\mathrm{T}_{5}$ treatment. $\mathrm{T}_{1}$ treatment produced the highest seed yield (1.90 t ha-1) in 2011-12 and 2.04 $\mathrm{t} \mathrm{ha}^{-1}$ in 2012-13. The maximum seed yield in $\mathrm{T}_{1}$ might be due to cumulative effect of yield contributing characters i.e. number of pod plant ${ }^{-1}$, number of seeds $\operatorname{pod}^{-1}$ and 1000- seed weight. 
Table 1. Seed yield and yield attributes of lentil as a mixed crop with rapeseed

\begin{tabular}{c|c|c|c|c|c|c}
\hline \multirow{2}{*}{ Treatments } & \multicolumn{2}{|c|}{ Plant height $(\mathrm{cm})$} & \multicolumn{2}{c|}{ Plant population $\mathrm{m}^{-2}$} & \multicolumn{2}{c}{ Number of pods plant $^{-1}$} \\
\cline { 2 - 6 } & $2011-12$ & $2012-13$ & $2011-12$ & $2012-13$ & $2011-12$ & $2012-13$ \\
\hline $\mathrm{T}_{1}$ & 48.10 & 50.63 & 119.96 & 126.1 & 57.18 & 46.55 \\
$\mathrm{~T}_{3}$ & 42.93 & 45.19 & 114.57 & 124.1 & 53.80 & 45.78 \\
$\mathrm{~T}_{4}$ & 42.29 & 44.52 & 118.48 & 123.1 & 48.56 & 45.70 \\
$\mathrm{~T}_{5}$ & 39.16 & 41.22 & 110.70 & 121.2 & 39.44 & 43.84 \\
$\mathrm{~T}_{6}$ & 40.36 & 42.48 & 114.97 & 122.2 & 51.33 & 44.42 \\
\hline LSD $_{(0.05)}$ & 2.512 & 0.643 & $\mathrm{NS}$ & $\mathrm{NS}$ & 11.74 & 0.198 \\
$\mathrm{CV}(\%)$ & 3.99 & 6.26 & 10.33 & 4.25 & 12.66 & 6.8 \\
\hline
\end{tabular}

Table 1. (Continued)

\begin{tabular}{c|cc|c|c|c|c}
\hline \multirow{2}{*}{ Treatments } & \multicolumn{2}{|c|}{ Number of seeds pod ${ }^{-1}$} & \multicolumn{2}{c|}{1000 - seed weight $(\mathrm{g})$} & \multicolumn{2}{c}{ Seed yield (t ha $\left.{ }^{-1}\right)$} \\
\cline { 2 - 7 } & $2011-12$ & $2012-13$ & $2011-12$ & $2012-13$ & $2011-12$ & $2012-13$ \\
\hline $\mathrm{T}_{1}$ & 1.68 & 1.65 & 18.32 & 18.91 & 1.90 & 2.04 \\
$\mathrm{~T}_{3}$ & 1.75 & 1.65 & 18.55 & 18.33 & 1.73 & 1.91 \\
$\mathrm{~T}_{4}$ & 1.72 & 1.65 & 18.25 & 18.32 & 1.80 & 1.91 \\
$\mathrm{~T}_{5}$ & 1.67 & 1.55 & 17.87 & 17.26 & 1.57 & 1.59 \\
$\mathrm{~T}_{6}$ & 1.70 & 1.65 & 18.53 & 18.23 & 1.78 & 1.82 \\
\hline $\operatorname{LSD}_{(0.05)}$ & 0.053 & 0.038 & 0.241 & 0.107 & 0.038 & 0.174 \\
$\mathrm{CV}_{(\%)}$ & 2.47 & 2.89 & 3.69 & 2.50 & 7.10 & 5.60 \\
\hline
\end{tabular}

\section{Yield and yield attributes of rapeseed}

Data as presented in the Table 2 revealed that yield and yield contributing characters of rapeseed were differed significantly different. There was an increasing trend of plant population with the increase of seed ratio in all the treatments. The maximum plant population (84.94 and 99.40) was observed in $\mathrm{T}_{2}$ treatment followed by $T_{5}$ and the lowest plant population (10.40 and 22.21) from $T_{3}$ treatment in 2011-12 and 2012-13,respectively. The maximum number of siliqua plant ${ }^{-1}$ (45.00) were found in $T_{3}$ which was statistically similar to $T_{6}, T_{4}$ and $T_{5}$ and the minimum (30.43) from $T_{2}$ treatment during 2011-12. Similar trend was observed in 2012-13. In 2011-12, the highest number of seeds siliqua ${ }^{-1}$ (32.34) was obtained from $\mathrm{T}_{4}$ followed by $\mathrm{T}_{6}$ as well as the lowest (29.83) was recorded from $\mathrm{T}_{2}$. More or less similar results were recorded in 2012-13. From two years result showed that there was no significant difference among the treatment regarding 1000- seeds weight (g) but numerically higher 1000- seeds weight (2.93 g in 2011-12 and 2.79 $\mathrm{g}$ in 2012-13) was observed in $\mathrm{T}_{3}$ followed by $\mathrm{T}_{2}$ and $\mathrm{T}_{6}$ but the lower (2.75 $\mathrm{g}$ in 201112 and $2.73 \mathrm{~g}$ in 2012-13) from $\mathrm{T}_{5}$ treatment. The maximum seed yields $1.65 \mathrm{t} \mathrm{ha}^{-1}$ and $2.12 \mathrm{t} \mathrm{ha}^{-1}$ were obtained in $\mathrm{T}_{2}$ followed by $\mathrm{T}_{5}$ due to higher plant population where as the minimum seed yield $(0.50 \mathrm{t}$ ha $^{-1}$ in 2011-12 and 0.55 t ha ${ }^{-1}$ in 2012-13) was obtained from $\mathrm{T}_{3}$ treatment, which were statistically similar to $\mathrm{T}_{6}$.

Table 2. Seed yield and yield attributes of rapeseed as a mixed crop with lentil

\begin{tabular}{c|c|c|c|c|c|c}
\hline \multirow{2}{*}{ Treatments } & \multicolumn{2}{|c|}{ Plant height $(\mathrm{cm})$} & \multicolumn{2}{c|}{ Plant population $\mathrm{m}^{-2}$} & \multicolumn{2}{c}{$\begin{array}{c}\text { No. of } \\
\text { siliquae plant }\end{array}$} \\
\cline { 2 - 7 } & $2011-12$ & $2012-13$ & $2011-12$ & $2012-13$ & $2011-12$ & $2012-13$ \\
\hline $\mathrm{T}_{2}$ & 74.71 & 82.64 & 84.94 & 99.40 & 30.43 & 30.48 \\
$\mathrm{~T}_{3}$ & 78.16 & 86.46 & 10.40 & 22.21 & 45.00 & 34.50
\end{tabular}


Islam et al.

\begin{tabular}{ccccccc}
$\mathrm{T}_{4}$ & 76.13 & 84.22 & 20.94 & 30.80 & 39.63 & 33.92 \\
$\mathrm{~T}_{5}$ & 72.72 & 80.44 & 33.37 & 39.20 & 37.50 & 31.14 \\
$\mathrm{~T}_{6}$ & 78.42 & 83.44 & 16.33 & 26.01 & 41.73 & 33.68 \\
\hline LSD $_{(0.05)}$ & 0.975 & 2.19 & 2.776 & 2.257 & 9.357 & 2.063 \\
$\mathrm{CV}(\%)$ & 7.63 & 6.45 & 5.77 & 6.87 & 12.89 & 5.70 \\
\hline
\end{tabular}

Table 2. (Continued)

\begin{tabular}{c|cc|c|c|c|c}
\hline \multirow{2}{*}{ Treatments } & \multicolumn{2}{|c|}{$\begin{array}{c}\text { No. of } \\
\text { seeds siliqua }\end{array}$} & \multicolumn{2}{c|}{1000 -seed weight (g) } & \multicolumn{2}{c}{ Seed yield $\left(\mathrm{t} \mathrm{ha}^{-1}\right)$} \\
\cline { 2 - 7 } & $2011-12$ & $2012-13$ & $2011-12$ & $2012-13$ & $2011-12$ & $2012-13$ \\
\hline $\mathrm{T}_{2}$ & 29.83 & 28.66 & 2.90 & 2.77 & 1.65 & 2.12 \\
$\mathrm{~T}_{3}$ & 30.67 & 29.98 & 2.93 & 2.79 & 0.50 & 0.55 \\
$\mathrm{~T}_{4}$ & 32.34 & 28.38 & 2.77 & 2.76 & 0.53 & 0.72 \\
$\mathrm{~T}_{5}$ & 30.20 & 27.64 & 2.75 & 2.73 & 0.62 & 0.82 \\
$\mathrm{~T}_{6}$ & 30.90 & 29.92 & 2.80 & 2.77 & 0.50 & 0.63 \\
\hline $\mathrm{LSD}_{(0.05)}$ & 0.059 & 1.668 & NS & 0.042 & 0.059 & 0.261 \\
$\mathrm{CV}(\%)$ & 5.11 & 4.30 & 7.72 & 3.65 & 6.29 & 12.08 \\
\hline
\end{tabular}

\section{Lentil equivalent yield and land equivalent ratio (LER)}

Data presented in the Table 3 revealed that the equivalent yield of lentil was differed from each other among the treatments in both the consecutive years. The maximum lentil equivalent yield $\left(2.22 \mathrm{t} \mathrm{ha}^{-1}\right)$ was obtained from $\mathrm{T}_{4}$ followed by $\mathrm{T}_{6}$ and $\mathrm{T}_{3}$ and the lowest lentil $\left(1.30 \mathrm{tha}^{-1}\right)$ in $\mathrm{T}_{2}$ treatment in 201112. Similar trends were observed in 2011-12. The highest lentil equivalent yield ( $\left.2.48 \mathrm{t} \mathrm{ha}^{-1}\right)$ was obtained from $T_{4}$ followed by $T_{6}$ and $T_{3}$ and the lowest lentil equivalent yield $\left(1.67 \mathrm{t} \mathrm{ha}^{-1}\right.$ ) was recorded in $T_{2}$ treatment. It was noted that all the mixed cropping system produced higher equivalent yield than that of their corresponding sole crops. Results from both the years indicated that $\mathrm{T}_{4}$ treatment was found higher yield advantageous as well as profitable over other treatments. Similar observations in different mixed/intercropping systems were reported by other authors (Ali et al., 2007, Patra et al., 2000; Islam et al., 2008 and Alom et al., 2008). The maximum land equivalent ratio (LER) 1.27 and 1.28 were observed in 2011-12 and 2012-13, respectively from the $\mathrm{T}_{4}$ treatment followed by $\mathrm{T}_{6}$. It is noted that all the mixed cropping systems showed higher LER than sole crop. It could be said that a farmer may increase his land use efficiency by 27 to $28 \%$ from mixed cropping systems from growing one hectare of land than that of their traditional sole crops cultivation. The results are in agreement with that of Santalla et al. (2001), Basak et al. (2006), Razzaque et al. (2007) and Alom et al. (2008).

Table 3. Lentil equivalent yield and land equivalent ratio (LER) of mixed cropping entil with rapeseed

\begin{tabular}{|c|c|c|c|c|c|c|c|c|}
\hline \multirow{3}{*}{ Treatments } & \multicolumn{4}{|c|}{ 2011-12 } & \multicolumn{4}{|c|}{$2012-13$} \\
\hline & \multicolumn{2}{|c|}{ Seed yield $\left(\mathrm{t} \mathrm{ha}^{-1}\right)$} & \multirow{2}{*}{$\begin{array}{c}\text { Lentil } \\
\text { equivalent } \\
\text { yield } \\
\left(\mathrm{t} \mathrm{ha}^{-1}\right) \\
\end{array}$} & \multirow{2}{*}{ LER } & \multicolumn{2}{|c|}{ Seed yield $\left(\mathrm{t} \mathrm{ha}{ }^{-1}\right)$} & \multirow{2}{*}{$\begin{array}{c}\text { Lentil } \\
\text { equivalent } \\
\text { yield }\left(\mathrm{t} \mathrm{ha}^{-1} \text { ) }\right.\end{array}$} & \multirow{2}{*}{ LER } \\
\hline & Lentil & Rapeseed & & & Lentil & Rapeseed & & \\
\hline $\mathrm{T}_{1}$ & 1.90 & - & 1.90 & 1.00 & 2.04 & - & 2.04 & 1.00 \\
\hline $\mathrm{T}_{2}$ & 0.00 & 1.65 & 1.30 & 1.00 & - & 2.12 & 1.67 & 1.00 \\
\hline $\mathrm{T}_{3}$ & 1.73 & 0.50 & 2.13 & 1.21 & 1.91 & 0.55 & 2.34 & 1.20 \\
\hline $\mathrm{T}_{4}$ & 1.80 & 0.53 & 2.22 & 1.27 & 1.91 & 0.72 & 2.48 & 1.28 \\
\hline $\mathrm{T}_{5}$ & 1.57 & 0.62 & 2.05 & 1.20 & 1.59 & 0.82 & 2.23 & 1.17 \\
\hline $\mathrm{T}_{6}$ & 1.78 & 0.50 & 2.18 & 1.24 & 1.82 & 0.63 & 2.32 & 1.19 \\
\hline
\end{tabular}

\section{Cost benefit analysis}


Data of cost and return analysis (average of two years) are presented in the Table 4. It showed that the highest gross return (Tk.164500 ha-1) and net return (Tk.127774 ha-1) were found maximum in $\mathrm{T}_{4}$ followed by $T_{6}$ and $T_{3}$ while sole rapeseed produced the lowest gross return (Tk.103950 ha ${ }^{-1}$ ) as well as net return (Tk.60540 ha-1). The cost of cultivation was found higher in sole rapeseed cultivation as it required more fertilizers, irrigation and labour costs than that of lentil cultivation. Net return was higher than mixed cropping system than that of sole cropping. Many investigators also reported higher net return in mixed/intercropping systems than sole crop (Quayyum and Maniruzzaman, 1995; Sarker and Pal, 2004; Basak et al., 2006; Razzaque et al., 2007; Pyare et al., 2008 and Alom et al., 2008). The highest benefit cost ratio (3.48) was recorded from $\mathrm{T}_{4}$ where as the minimum BCR (1.39) from $\mathrm{T}_{2}$ treatment.

Table 4. Cost and return analysis obtained from the experimentation (average of two years)

\begin{tabular}{|c|c|c|c|c|c|}
\hline Treatments & $\begin{array}{l}\text { Lentil equivalent yield } \\
\qquad\left(\mathrm{t} \mathrm{ha}^{-1}\right)\end{array}$ & $\begin{array}{l}\text { Gross return } \\
\left(\mathrm{Tk}^{\left.-\mathrm{ha}^{-1}\right)}\right.\end{array}$ & $\begin{array}{l}\text { Total cost } \\
\left(\mathrm{Tk} . \mathrm{ha}^{-1}\right)\end{array}$ & $\begin{array}{l}\text { Net return } \\
\left(\mathrm{Tk} . \mathrm{ha}^{-1}\right)\end{array}$ & $\begin{array}{c}\text { Benefit } \\
\text { cost ratio } \\
\text { (BCR) }\end{array}$ \\
\hline $\mathrm{T}_{1}$ & 1.97 & 137900 & 36464 & 101436 & 2.78 \\
\hline $\mathrm{T}_{2}$ & 1.49 & 103950 & 43410 & 60540 & 1.39 \\
\hline $\mathrm{T}_{3}$ & 2.24 & 156450 & 36595 & 119855 & 3.28 \\
\hline $\mathrm{T}_{4}$ & 2.35 & 164500 & 36726 & 127774 & 3.48 \\
\hline $\mathrm{T}_{5}$ & 2.14 & 149800 & 36857 & 112943 & 3.06 \\
\hline $\mathrm{T}_{6}$ & 2.25 & 157500 & 36661 & 120840 & 3.30 \\
\hline \multicolumn{3}{|c|}{ Price of Input (Tk. $\left.\mathrm{kg}^{-1}\right)$} & \multicolumn{3}{|c|}{ Price of output (Tk. $\left.\mathrm{kg}^{-1}\right)$} \\
\hline Seed & \multirow{2}{*}{$\begin{array}{l}110 \\
20.0\end{array}$} & & \multicolumn{2}{|c|}{ Lentil grain } & 70.0 \\
\hline Urea & & & \multicolumn{2}{|l|}{ Rapeseed } & 55.0 \\
\hline TSP & 24.0 & & & & \\
\hline MoP & 15.0 & & & & \\
\hline Gypsum & 10.0 & & & & \\
\hline $\mathrm{ZnSO}_{4}$ & 130.0 & & & & \\
\hline Boric acid & 130.0 & & & & \\
\hline
\end{tabular}

\section{Conclusion}

Lentil equivalent yield was increased with the increase in percent of rapeseed up to $20 \%$ with $100 \%$ lentil and thereafter it declined with further increment in seeds. All the mixed crop combinations showed higher gross return as well as net return than the respective sole crops. Considering the yield and return it can be concluded that treatment $\mathrm{T}_{4}$ viz. 100\% lentil with $20 \%$ rapeseed $(30 \mathrm{~kg}$ lentil with $2.0 \mathrm{~kg}$ rapeseed per hectare) was the most profitable one compared to other treatments when grown as mixed crop. Furthermore, mixed cropping was found more profitable than the sole.

\section{References}

Ali, M. 1990. Pigeonpea: Cropping systems. The pegionpea CAB International ICRISAT, Patancheru, A.P. 502324, India. pp.281-282.

Ali, M. O., M. J. Alam, M. S. Alam, M. A. Islam and M. Shahin-uz-zaman. 2007. Study on Mixed Cropping Mungbean with Sesame at Different Seeding Rates. Intl. J. Sustain. Crop Prod. 2: 74-77. 
Islam et al.

Alom, M. S., N. K. Paul, and M. A. Quayyum. 2008. Performance of hybrid maize (Zea mays L.) under intercropping systems with mungbean (Vigna radiata L.) in different planting methods. SAARC J. Agri. 6: 73-82.

Altieri, M. A. 1999. The ecological role of biodiversity in agroecosystems. Agric. Ecosys. Environ.74 : 19-31.

Altieri, M. A., D. K. Letourneau and J. R. Davis. 1983. Developing sustainable agroecosystems. BioSci. 33: 45-49.

Anil, L., J. Park, R. H. Phipps and F. A. Miller. 1998. Temperate intercropping of cereals for forage: A review of the potential for growth and utilization with particular reference to the UK. Grass Forage Sci 53: 301-317.

Anjeneyula, V. R., S. P. Singh and M. Ali. 1982. Effect of competition free period and technique and pattern of pearl millet planting in growth and yield of mungbean and total productivity in solid pearl millet and pearl millet/mungbean intercropping systems. Indian J. Agron. 27: 219-226.

Bangladesh Bureau of Statistics (BBS). 2010. Yearbook of Agricultural Statistics of Bangladesh. Reproduction, Documentation and Publication Wing, BBS, Secretariat, Dhaka.

Basak, N. C., S. M. A. Hossain, I. Islam and N. I. Bhuiyan. 2006. Intercropping wheat with groundnut at variable plant population Bangladesh J. Agril. Res. 31: 207-215.

Bulson, H. A. J., R.W. Snaydon and C. E. Stopes. 1997. Effects of plant density on intercropped wheat and filed beans in an organic farming system. J Agr. Sci 128: 59-71.

Chowdhury, S. L. 1981. Recent studies in intercropping systems on proceedings of the India-some thoughts, some results. In: Proceed. Intl. Workshop Intercrop., 10-13 January, 1979 ICRISAT, Patancheru, A.P. 502324, India. pp.299-305.

Gomez, K. A. and A. A. Gomez. 1984. Statistical Proc. Agric. Res. (2nd edition), Jhon Willey and Sons, New York.

Islam, M. N. and M. Akteruzzaman. 2008. Survey on multiple cropping systems in farmers field. In: Annual Research Report 2007-08, Agronomy Division, BARI, Joydebpur, Gazipur. pp.44-48.

Jensen, E. S., H. Hauggaard-Nielsen, J. Kinane, M. K. Andersen and B. Jornsgaard. 2005. Intercropping - The practical application of diversity, competition and facilitation in arable organic cropping systems. In: Kopke U, Niggli U, Neuhoff D, Lockeretz W, Willer H (eds) Researching Sustainable Systems 2005. Proceedings of the First Scientific Conference of the International Society of Organic Agricultural Research (ISOFAR), Bonn, Germany, 2005, pp.22-25.

Jackson, L. E., U. Pascual and T. Hodgkin. 2007. Utilizing and conserving agrobiodiversity in agricultural landscapes. Agro. Eco. Env. 121: 196-210.

McGilchrist, C. A. and B. R. Trenbath. 1971. A revised analysis of plant competition experiments. Biometrics 27: 659-671.

Malézieux, E., Y. Crozat, C. Dupraz, M. Laurans, D. Makowski, H. Ozier-Lafontaine, B. Rapidel, S. Tourdonnet and M. Valantin-Morison. 2009. Mixing plant species in cropping systems: concepts, tools and models. A review. Agron. Sustain. Dev. 29: 43-62.

Ofori, F. and W. R. Stern. 1987. Cereal-legume intercropping systems. Adv. Agron. 41: 41-90.

Patra, B. C., B. K. Mandal and A. L. Padhi. 2000. Production potential of winter maize (Zea mays L.) based intercropping systems. Indian J. Agric. Sci. 70: 2003-2006.

Pyare, R., K. Prasad, S. Kumar, R. K.Tiwari and T. C. Sonkar. 2008. Production potential and economics of lentil (Lens esculenta) and mustard (Brassica juncea) in mixed and intercropping system. Plant Archives 8(1). pp.233-236.

Quayyum, M. A. and A. F. M. MAniruzzaman. 1995. Effect of maize (Zea mays L.) and rice (Oryza sativa) with Blackgram (Phaseolus mungo). Indian J. Agron. 40(1): 20-25. 
Mixed Cropping of Lentil with Rapeseed

Razzaque, M. A., S. Rafiquzzaman, M. M. M. Bazzaz, A. Ali and M. M. R. Talukdar. 2007. Study on the intercropping groundnut with chilli at different plant populations. Bangladesh J. Agril. Res. 32(1): 3743.

Santalla, M., A. P. Rodino, P. A. Casquero and A. M. De Ron. 2001. Interactions of bush bean intercropped with field and sweet maize. European J. Agron. 15: 185-196.

Sarkar, R. K. and P. K. Pal. 2004. Effect of intercropping rice (Oryza sativa) with groundnut (Arachis hypogaea) and pigeonpea (Cajanas cajan) under different row orientations on rainfed uplands. Indian J. Agron. 49(3): 147-150.

Scherr, S. J. and J. A. McNeely. 2008. Biodiversity conservation and agricultural sustainability: towards a new paradigm of 'ecoagriculture' landscapes. Phil. Trans. R. 363: 477-494.

Thrupp, L. A. 2002. Linking agricultural biodiversity and food security: the valuable role of agrobiodiversity for sustainable agriculture. Intl. Aff. 76: 283-297.

Theunissen, J. 1997. Intercropping in field vegetables as an approach to sustainable horticulture. Outlook Agr. 26: 95- 99.

Willey, R. W. 1981. A scientific approach to intercropping research. In: Proc. Intl. Workshop Intercrop. 10-13 January, 1979, ICRISAT, Patancheru, A.P. 502324, India. pp.4-14.

Willey, R. W. and M. R. Rao. 1981. A competitive ratio for quantifying competition between intercrops. Expt. Agric. 16: 117-125. 
Islam et al. 